\title{
Mongolia: Joint IMF/World Bank Debt Sustainability Analysis Under the Debt Sustainability Framework for Low-Income Countries
}

This Debt Sustainability Analysis Under the Debt Sustainability Framework for Low-Income Countries on Mongolia was prepared by a staff team of both the International Monetary Fund and the World Bank as background documentation for the periodic consultation with the member country. It is based on the information available at the time it was completed on May 5, 2010. The views expressed in this document are those of the staff team and do not necessarily reflect the views of the government of Mongolia or the Executive Board of the IMF.

The policy of publication of staff reports and other documents by the IMF allows for the deletion of market-sensitive information.

Copies of this report are available to the public from

International Monetary Fund • Publication Services

$70019^{\text {th }}$ Street, N.W. • Washington, D.C. 20431

Telephone: (202) 623-7430 • Telefax: (202) 623-7201

E-mail: publications@imf.org Internet: http://www.imf.org

\section{International Monetary Fund Washington, D.C.}




\title{
INTERNATIONAL MONETARY FUND \\ INTERNATIONAL DEVELOPMENT ASSOCIATION
}

MONGOLIA

\section{Joint IMF/World Bank Debt Sustainability Analysis Under the Debt Sustainability Framework for Low-Income Countries ${ }^{1}$}

\author{
Approved by Nigel Chalk and David Marston (IMF) \\ and Sudarshan Gooptu and Vikram Nehru (IDA)
}

May 5, 2010

\begin{abstract}
The staff's debt sustainability analysis (DSA) shows that Mongolia is at low risk of external debt distress. After rising significantly over the period 2009-10, as the government has been receiving front-loaded foreign financing to recover from major terms of trade shock, the debt outlook is expected to recover and improve over the medium term. Although the public DSA suggests that in light of the signing of the Oyu Tolgoi mining agreement domestic debt will rise in the medium term, it does not lead to a different sustainability assessment.
\end{abstract}

\section{BACKGROUND}

\section{This joint DSA update incorporates the fiscal costs associated with banking sector} restructuring and the recently signed Oyu Tolgoi mining agreement. ${ }^{2}$ It assumes that Mongolia achieves sustainable growth by maintaining prudent macroeconomic and structural policies, including the establishment of a fiscal framework to avoid procyclical policies. Specifically, in light of plans under the draft fiscal stability law, the phasing out of donor

\footnotetext{
${ }^{1}$ The DSA has been produced jointly by the staffs of the International Monetary Fund and the World Bank, in consultation with the Asian Development Bank (AsDB) and the Mongolian authorities (Debt Management Department and Aid Coordination Department of the Ministry of Finance). The fiscal year for Mongolia is January-December.

${ }^{2}$ The DSAs presented in this document are based on the common standard low-income countries (LIC) DSA framework. Under the Country Policy and Institutional Assessment (CPIA), Mongolia is rated as a medium performer with an average rating of 3.3 between 2006-08, and the DSA uses the indicative threshold indicators for countries in this category. See "Debt Sustainability in Low-Income Countries: Proposal for an Operational Framework and Policy Implications" (http:/www.imf.org/external/np/pdr/sustain/2004/020304.htm and IDA/SECM2004/0035, 2/3/04) and "Debt Sustainability in Low-Income Countries: Further Considerations on an Operational Framework, Policy Implications" (http://www.imf.org/external/np/pdr/sustain/2004/091004.htm and IDA/SECM2004/0629, 9/10/04) and "Applying the Debt Sustainability Framework for Low-Income Countries Post Debt Relief," (8/11/06).
} 
budgetary support, and a desire to not crowd out the private sector, the authorities continue with fiscal adjustment until revenues from the Oyu Tolgoi mine, net of amortization, start to hit the budget (around 2016). Good macroeconomic policies will also help avoiding "the resource curse."

Compared to the previous DSA the macroeconomic outlook has improved, supported by Mongolia's strong policy implementation under the SBA-supported program. Market conditions have improved and monetary policy has brought down inflation and rebuilt international reserves with comfortable margins relative to program floors. The growth profile has been updated in line with revised production estimates for the Oyu Tolgoi mine over the medium and long term (Box 1).

\section{Box 1. Mongolia-The Oyu Tolgoi Mining Project}

Oyu Tolgoi is the world's largest undeveloped copper-gold project and is located just north of the MongolianChinese border. An investment agreement to develop the Oyu Tolgoi deposits was concluded in October 2009 between Rio Tinto International (a British-Australian mining company), Ivanhoe Mines Ltd (Canadian), Ivanhoe Mines Mongolia Inc LLC, and the Government of Mongolia.

A key aspect of the agreement is that the government will hold a 34 percent equity share in Ivanhoe Mines Mongolia Inc LLC, which is the license holder of the Oyu Tolgoi project. The government's participation is financed as a domestic but US\$-denominated loan of around US\$870 million from Ivanhoe Mines Mongolia, and along with advance payments of US\$250 million for budget financing, becomes due for repayment from 2014 onwards. Other important terms include a stable operational and tax environment. Ivanhoe will retain a controlling 66 percent equity share in the Oyu Tolgoi project (with Rio Tinto currently owning a 22 percent share in Ivanhoe).

Ivanhoe-Rio Tinto is expected to spend US\$758 million in 2010 to begin the full-scale construction of the mine and similarly large amounts are expected to be spent in the next few years. As mining-related imports increase, the current account deficit is accordingly expected to worsen significantly in the near term as mining-related imports increase. However, this will be mirrored by large capital inflows in the financial account. Production is projected to start in 2013 and is expected to produce 500,000 tons of copper and 500,000 ounces of gold per year on average for at least 35 years, with the life of the mine estimated at around 60 years. Revenues, that is, corporate income tax, royalties, VAT, and dividends, from Oyu Tolgoi are expected to enter the budget from 2016 onwards. However, only around 2016 will net revenues, that is, after amortization of the prepayment and equity share loans, enter the budget.

Sources: Rio Tinto, IMF, and World Bank.

\section{Mongolia's economic prospects also received a big boost with the signing of the Oyu} Tolgoi investment agreement at the end of 2009. Growth, after bottoming out in 2009, is projected to rebound to 7 percent this year, driven largely by capital expenditures related to the Oyu Tolgoi mine. Even though much of the investment will be met through imports, there will be substantial spillovers to the domestic economy. In addition, copper prices have 
rebounded and are projected to be significantly higher than projected in the previous joint DSA. ${ }^{3}$ Other major mining projects are being explored which could further improve the outlook. $^{4}$

\section{Mongolia's stock of external debt as of end-2009 is estimated at US\$2.1 billion (50 percent of GDP). This includes public or publicly guaranteed debt (PPG) of US $\$ 2.0$ billion as reported by the Ministry of Finance and estimated private external debt of US\$0.1 billion. Most of Mongolia's public debt is external with about 64 percent}

Mongolia: Structure of External Public Debt

\begin{tabular}{cccc}
\hline & \multicolumn{2}{c}{ End-2009 Nominal } & $\begin{array}{c}\text { End-2009 } \\
\text { Present Value }\end{array}$ \\
\cline { 2 - 3 } & USD mn & \% of GDP & \\
\hline Public debt & 1,977 & 47.1 & 1,457 \\
Multilaterals & 1,253 & 29.8 & 883 \\
IMF & 182 & 4.3 & 166 \\
World Bank & 392 & 9.3 & 239 \\
AsDB & 627 & 14.9 & 447 \\
Official bilaterals & 650 & 15.5 & 494 \\
Paris Club & 508 & 12.1 & 380 \\
Non-Paris Club & 142 & 3.4 & 114 \\
Commercial & 75 & 1.8 & 80
\end{tabular}

Sources: Mongolian Ministry of Finance, AsDB, WB and IMF staff estimates. of external debt contracted with multilateral creditors on concessional terms, 32 percent with official bilateral creditors on relatively concessional terms and 4 percent with commercial banks.

The recent increase in the external debt stock reflects donor financing, including Fund and Bank lending to help Mongolia smooth its fiscal adjustment path after the major terms of trade shock in 2008.

Mongolia's external PPG debt burden rose to 47 percent of GDP in 2009 from 34 percent of GDP in 2008. The increase came after strong reductions in debt in previous years due to high rates of economic growth and prudent debt

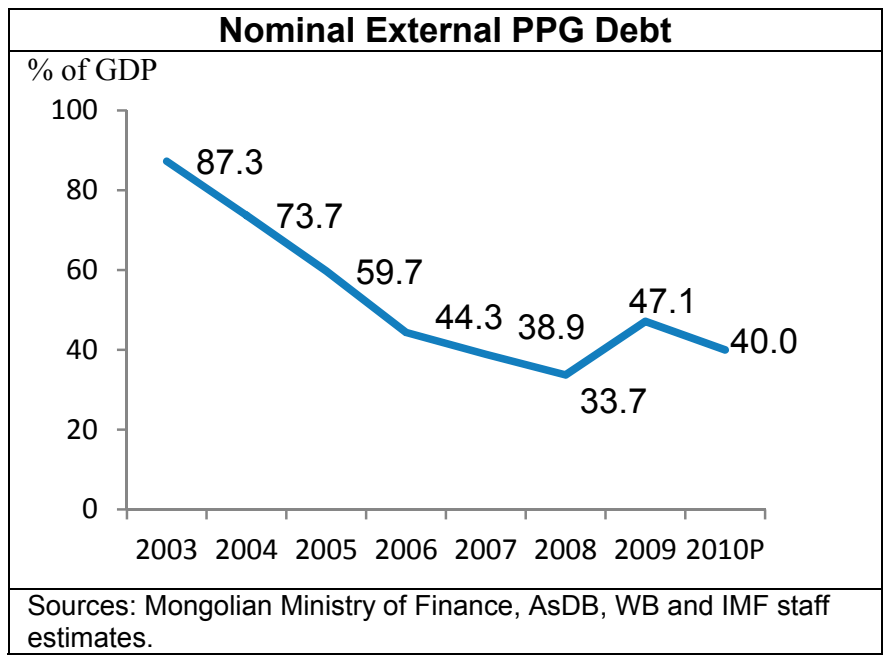
management policies, which reduced its external PPG debt from 87 percent of GDP in 2003.

\footnotetext{
${ }^{3}$ See "Mongolia: Request for Stand-By Arrangement," April 2009 (IMF Country Report No. 09/130), and, IDA/R2009-0175/1 (World Bank).

${ }^{4}$ The Tavan Tolgoi deposit, close to the border with China, if developed, would make Mongolia a major world coal producer. However, the Tavan Tolgoi project has not been incorporated in the underlying baseline macroeconomic framework due to the uncertainties about its size and timeframe for development. Once Tavan Tolgoi materializes, it is projected to have an important short-term impact via increased equipment imports, FDI, and loan inflows, and a medium- to long-term beneficial impact on the current account, similar to Oyu Tolgoi.
} 
The fiscal deficit, which will be financed primarily by domestic sources, is expected to steadily decline until revenues from the Oyu Tolgoi mine enter the budget.

The composition of domestic debt reflects the Oyu Tolgoi project and bank restructuring financing. ${ }^{5}$ The $\mathrm{Oyu}$ Tolgoi loans have been contracted from a resident company in U.S. dollars. The banking restructuring bonds are domestic currency denominated and assumed to be repaid after 10 years for an amount of about Tog 520 billion. $^{6}$

Mongolia's debt management capacity remains low, but progress has been made in some areas. The World Bank's 2008 Debt Management Performance Assessment (DeMPA) found that Mongolia scored poorly on indicators relating to operational risk management and cash flow forecasting and cash balance management. However, it noted its relatively better performance vis-à-vis strategy development, coordination with macroeconomic policies, recording and reporting, key elements considering the large up-front external borrowing in 2009 and 2010. In addition, since that assessment, Mongolia has improved debt management procedures and has prepared a medium-term debt management strategy. ${ }^{8}$

\section{UNDERLYING DSA ASSUMPTIONS}

The baseline assumes a strong institutional framework and macroeconomic policies to minimize Dutch disease effects (Box 2). Following the surge in mining production from the Oyu Tolgoi mine, Mongolia will likely experience a substantial real appreciation creating challenges to maintaining low inflation and developing the nonmineral economy. The baseline assumes a restrained fiscal policy, supported by the adoption of a fiscal stability law. ${ }^{9}$ The fiscal stability law will promote the needed budget discipline by constraining policymakers' discretion. The law would put in place three complementary rules that would function as a fiscal "circuit breaker" and would work together to ensure fiscal discipline: (i) a ceiling on the "structural" deficit, (ii) a debt ceiling, and (iii) a ceiling on expenditure growth. Finally, it assumes that structural fiscal reforms including pensions, civil service, and subsidy

\footnotetext{
${ }^{5}$ However, roughly one-third of total domestic debt in 2009 is accounted for by short-term debt issued for budgetary financing.

${ }^{6}$ The Oyu Tolgoi investment share loan will be disbursed and repaid based on cash flow projections, which are subject to changes in commodity price assumptions.

${ }^{7}$ Conducted by the World Bank in June 2008.

${ }^{8}$ In 2009, the Debt Management Division of the Ministry of Finance (MoF) revised its previous debt management strategy, developing it as a medium-term strategy for 2010-12. This medium-term framework creates the opportunity for the government and $\mathrm{MoF}$ to improve future risk management.

${ }^{9}$ The fiscal stability law was submitted to parliament on January 12, 2010.
} 
reforms will contribute to an improved business climate and overall competitiveness of the economy.

\section{Box 2. Mongolia-Macroeconomic Assumptions}

The baseline macroeconomic framework assumes that the economy will be underpinned by the investment in the Oyu Tolgoi mine. The construction and exploitation of the Oyu Tolgoi copper and gold mine are expected to lead to significant structural changes in the economy.

- The outlook for real GDP growth is dominated by the Oyu Tolgoi mine. The scaling up of mining will increase mineral GDP and will have significant second-round effects on other sectors through a reallocation of resources and changes in relative prices. After bottoming out at minus 1.6 percent, real GDP growth is expected to rebound to over 7 percent in 2010, boosted by Oyu Tolgoi-related capital expenditures. Once production from the Oyu Tolgoi mine starts in 2013, it will boost growth to over 25 percent. Real GDP growth is expected to average 10 percent over the medium term (2014-20), taking into account the impact on the nonmineral economy.

- The copper price projections through 2015 are based on the WEO projections as of February 19, 2010 and are assumed constant in real terms afterwards.

- Given the fiscal adjustment under the Fund-supported program, and a tightening of monetary policy, inflation is projected to converge to about 5 percent over the long term.

- The balance of payments will go through large swings. The current account will remain in deficit of around 17 percent of GDP between 2010 and 2012 due to large imports of mining-related investment goods. As the project comes on stream, the current account will jump into a surplus.

- After a period of consolidation, the overall fiscal deficit is expected to converge to a new equilibrium. Fiscal revenues will be boosted by the Oyu Tolgoi project and are expected to reach 30 percent of GDP in 2016 (or 60 percent of nonmineral GDP), gradually converging to 27 percent of GDP by 2030 . The fiscal stability law will reduce pro-cyclicality by restraining expenditure growth during periods of high mineral revenues and enable the authorities to save a substantial fraction of mineral revenues. As a result, the overall balance would be in substantial surplus in 2014-20 and would then gradually converge to balance by 2030 .

- Private external debt, portfolio investment, and FDI are expected to increase in line with the development of mining projects, which will substantially help to sustain growth and build international reserves.

The borrowing assumptions reflect Mongolia's move to middle-income status. As the mining projects come on stream, Mongolia is expected to become eligible for nonconcessional borrowing from both the IBRD and the AsDB, which would be phased in starting in 2013. After that point, the concessionality of new external borrowing - as reflected by the grant-equivalent financing component - is projected to decline from 
37 percent in 2012 to 27 percent by $2030 .{ }^{10}$ Interest rates reflect IDA blend terms and AsDB terms for concessional borrowing and market conditions for commercial loans (although present conditions on the international capital markets for low-rated, first-time issuers may not be favorable, see Box 3).

\section{Debt SustainabiLity}

\section{A. External DSA}

Mongolia is at low risk of debt distress. All debt indicators remain below the relevant thresholds. ${ }^{11}$ Under the baseline, external debt indicators drop sharply in the near term, as the economy rebounds first due to Oyu Tolgoi-related investment spending and then supported by the production from the mine. The large loan repayments in 2013, in particular to the Fund, will reduce the debt stock, and debt ratios will stabilize thereafter. The present value (PV) of external public debt is forecasted to fall from 29 percent in 2010 to 13 percent of GDP at the end of the projection period. ${ }^{12}$

\section{External public debt service remains manageable, despite the expected repayment} clustering in 2012-14. The government has opportunistically built reserves over the past year, over performing relative to the floors in the Fund-supported program, and is expected to further increase its reserves. Debt service ratios rise sharply in 2013-14 as multilateral donors are repaid, but remain low compared to thresholds, and fall back to roughly half their levels in 2013 over the medium to long term. Nevertheless, it is important that in the near term Mongolia maintains a prudent fiscal stance, saves the advance prepayments from the Oyu Tolgoi project, and continues to opportunistically build reserves in order to ensure adequate liquidity over this period.

Stress tests do not indicate any breach of the relevant debt thresholds. Under the most extreme test - a one-time nominal depreciation of 30 percent relative to the baseline- the PV of debt-GDP ratio climbs 7 percentage points to 36 percent in 2011 but then falls back over the remainder of the projection period.

\footnotetext{
${ }^{10}$ Mongolia's 2008 GNI per capita is already above the threshold to be potentially eligible for IBRD loans .

${ }^{11}$ The Staff Guidance Note on the Application of the Joint Fund-Bank Debt Sustainability Framework for Low-Income Countries defines a "low risk of debt distress" when: "All debt indicators are well below relevant country-specific debt-burden thresholds. Stress testing and country-specific alternative scenarios do not result in indicators significantly breaching thresholds. In case where only one indicator is above its benchmark, judgment is needed to determine whether there is a debt sustainability problem or some other issues.

${ }^{12}$ The debt burden thresholds for medium policy performer are 150, 40, and 250 for the PV of debt in percent of exports, GDP, and revenue, respectively. Under the same medium policy classification, thresholds for debt service are 20 percent and 30 percent of exports and revenue, respectively.
} 


\section{Box 3. Sovereign Bond Spreads in 2009}

Emerging market bond spreads have fallen considerably since mid -2009 after widening to close to 800 basis points (bps) over U.S. treasuries last year, as concerns about large government contingent liabilities vis-à-vis potential bank recapitalizations eased and investor risk aversion declined. Although EMBI spreads are slightly above $300 \mathrm{bps}$, there are important differences between countries, notably those relating to sustainability of public finances, the likelihood of debt distress, and whether efforts at fiscal consolidation are credible.

Emerging market economies issued a total of

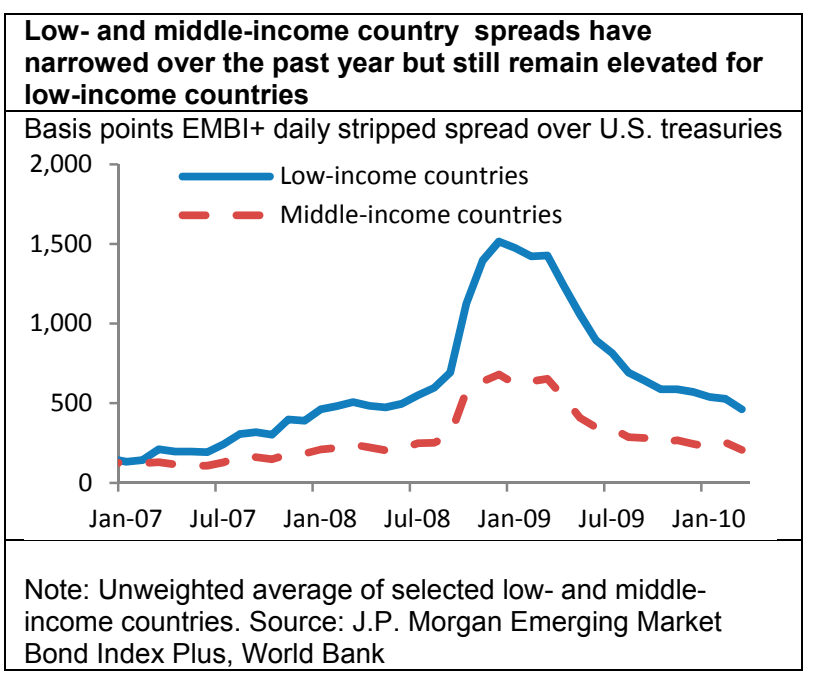
US $\$ 35$ billion of sovereign bonds in the first 10 months of 2009 . However the cost of borrowing varied considerably. For example, for countries with a relatively high investment grade rating (S\&P rating of $\mathrm{A}, \mathrm{BBB}+$ and $\mathrm{BBB}$ ) bond spreads were some $300 \mathrm{bps}$ higher relative to the government benchmark rate and 280 bps above the London Interbank Offer Rate (LIBOR). In comparison, countries rated less favorably (S\&P rating of BBB-) were higher (see table below). Spreads for Indonesia, which has a sub-investment grade rating (BB-), were more than 800 basis points higher than either the government or the LIBOR benchmarks. ${ }^{1}$

\begin{tabular}{|c|c|c|c|c|c|c|c|}
\hline \multirow[t]{2}{*}{ Country } & \multirow{2}{*}{$\begin{array}{c}\text { S\&P } \\
\text { rating }\end{array}$} & \multirow{2}{*}{$\begin{array}{l}\text { Moody's } \\
\text { rating }\end{array}$} & \multirow{2}{*}{$\begin{array}{l}\text { Coupon } \\
\text { rate }\end{array}$} & \multirow[t]{2}{*}{ Maturity } & \multirow{2}{*}{$\begin{array}{l}\text { US\$ } \\
(\mathrm{mn})\end{array}$} & \multicolumn{2}{|c|}{ Spread (bps) over } \\
\hline & & & & & & $\begin{array}{l}\text { Government } \\
\text { Benchmark }\end{array}$ & LIBOR \\
\hline Columbia & BBB- & $\mathrm{Ba} 1$ & 7.4 & 10 & 1,000 & 503 & 465 \\
\hline Peru & BBB- & $\mathrm{Ba} 1$ & 7.2 & $10-15$ & 1,500 & 391 & 371 \\
\hline Brazil & BBB- & $\mathrm{Ba} 1$ & 6.1 & $10-30$ & 3,525 & 248 & 243 \\
\hline Indonesia & BB- & Ba3 & 11.0 & $5-10$ & 3,000 & 865 & 829 \\
\hline Philippines & NA & B1 & 8.4 & 10 & 1,500 & 600 & 575 \\
\hline Sri Lanka & $B$ & not rated & 7.4 & 5 & 500 & 506 & 468 \\
\hline
\end{tabular}

Source: World Bank staff.

This shows that the market conditions remain very difficult for low-rated sovereigns. Indeed sovereign bond spreads have surged again and market appetite for sovereign bonds from such countries decreased in recent months, first due to the debt standstill by Dubai World, a state backed property venture in Dubai, and now most recently on account of solvency fears about Greece as well as other developed economies such as Portugal and Spain, with large fiscal deficits and rising debt ratios. This suggests that a first-time issuer in financial difficulties may also find it quite costly to enter the market at this stage.

${ }^{1}$ Although Mongolia has no outstanding international bonds, parliament has authorized the government to issue up to US $\$ 1.2$ billion. Fitch ratings currently assigns a notional B rating (sub-investment grade) to Mongolia's long-term external debt with a stable outlook, which is an improvement compared to early 2009, when it had a negative outlook. Other sovereigns with a similar rating include Ecuador, Ghana, Lebanon, Sri Lanka, Ukraine, and Venezuela. 
The historical scenario is not applicable to Mongolia with key variables at their historical averages throughout the projection period as the country is undergoing a major structural shift as real GDP growth is expected to jump from 6 percent in 2012 to 28 percent in 2013.

\section{B. Public DSA}

Public debt has increased substantially compared to the previous DSA due to the domestic financing of the Oyu Tolgoi project and banking restructuring costs. The baseline includes (i) fiscalization of banking sector restructuring costs through domestic bond issuances, and (ii) loans to the government from the local mining company for financing the government's investment share and a prepayment on future revenues.

The government has contracted borrowing agreements with the domestic counterpart of the mining conglomerate. The government will borrow US\$50 million for budget financing in 2010 after US\$100 million were disbursed in 2009, and an additional US\$100 million in 2011. An estimated additional US\$870 million will be borrowed to finance the government's 34 percent investment share in the project. As both loans will be contracted from a resident company, their impact is reflected in the public DSA.

As a result, public sector domestic debt service ratios are projected to increase sharply during 2014-17 as these loans are being repaid. The advance payment loans will be repaid from the general budget, while government's investment share borrowing will be repaid from accrued dividends (the government will not be liable for the loan in the unlikely event that dividends are insufficient).

The authorities are developing a comprehensive bank restructuring plan, with technical assistance provided by Bank and Fund staff. Costs associated with the restructuring are assumed to be fiscalized through the issuance of government bonds at an estimated 8 percent of GDP by 2010.

The risks for fiscal sustainability have increased over the medium term but remain low. ${ }^{13}$ The government will receive dividends from its share in the Oyu Tolgoi mine and government deposits are expected to increase, providing a comfortable cushion. For these reasons fixing the primary balance permanently at the 2010 deficit of 3 percent of GDP cannot be considered a realistic worst-case scenario for Mongolia. The permanent growth shock scenario is unrealistic given Mongolia's mining prospects, both in the investment phase and the operational phase of the Oyu Tolgoi project.

The high-investment-low-growth scenario is not relevant for Mongolia. The increase in public debt related to the Oyu Tolgoi project does not have an impact on investment and

\footnotetext{
13 The public DSA is conservatively undertaken on a gross debt rather than on a net debt basis.
} 
growth. The investment and production at the Oyu Tolgoi mine and, therefore, the economy's projected growth path do not depend on the government's participation. Once the mine starts production, the mining volume is virtually irresponsive to price changes. The impact of lower-than-projected growth is covered in the growth shock and alternative lower growth scenario.

\section{Authorities' VIEW}

The authorities concurred with the overall assessment. They acknowledged that the bridging to the start of the Oyu Tolgoi mining in 2013 will be key, and that fiscal consolidation will be needed. They recognized that high public debt makes the economy vulnerable to commodity price changes, or financing constraints and that a debt ceiling rule could prevent excessive borrowing against future wealth and reinforce the government's commitment to fiscal sustainability. Finally, they agreed with the assessment of the risk posed to Mongolia's debt outlook from contracting large amounts of commercial external debt to finance the budget.

\section{Conclusions}

\section{The overall assessment has not changed since the last DSA and the external DSA} indicates that Mongolia remains at low risk of external debt distress. The short-term macroeconomic outlook has improved due to strong performance under the SBA and a more favorable global outlook than envisaged at the outset of the program. The increase in domestic debt, albeit from a low level, does not lead to a different sustainability assessment that under the external DSA. Consequently, Mongolia would benefit from fiscal discipline until a sustainable flow of mineral revenues is established along with prudent nonconcessional borrowing consistent with debt sustainability, and sensible debt management. 
Figure 1. Mongolia: Indicators of Public and Publicly Guaranteed

External Debt Under Alternatives Scenarios, 2010-30 1/
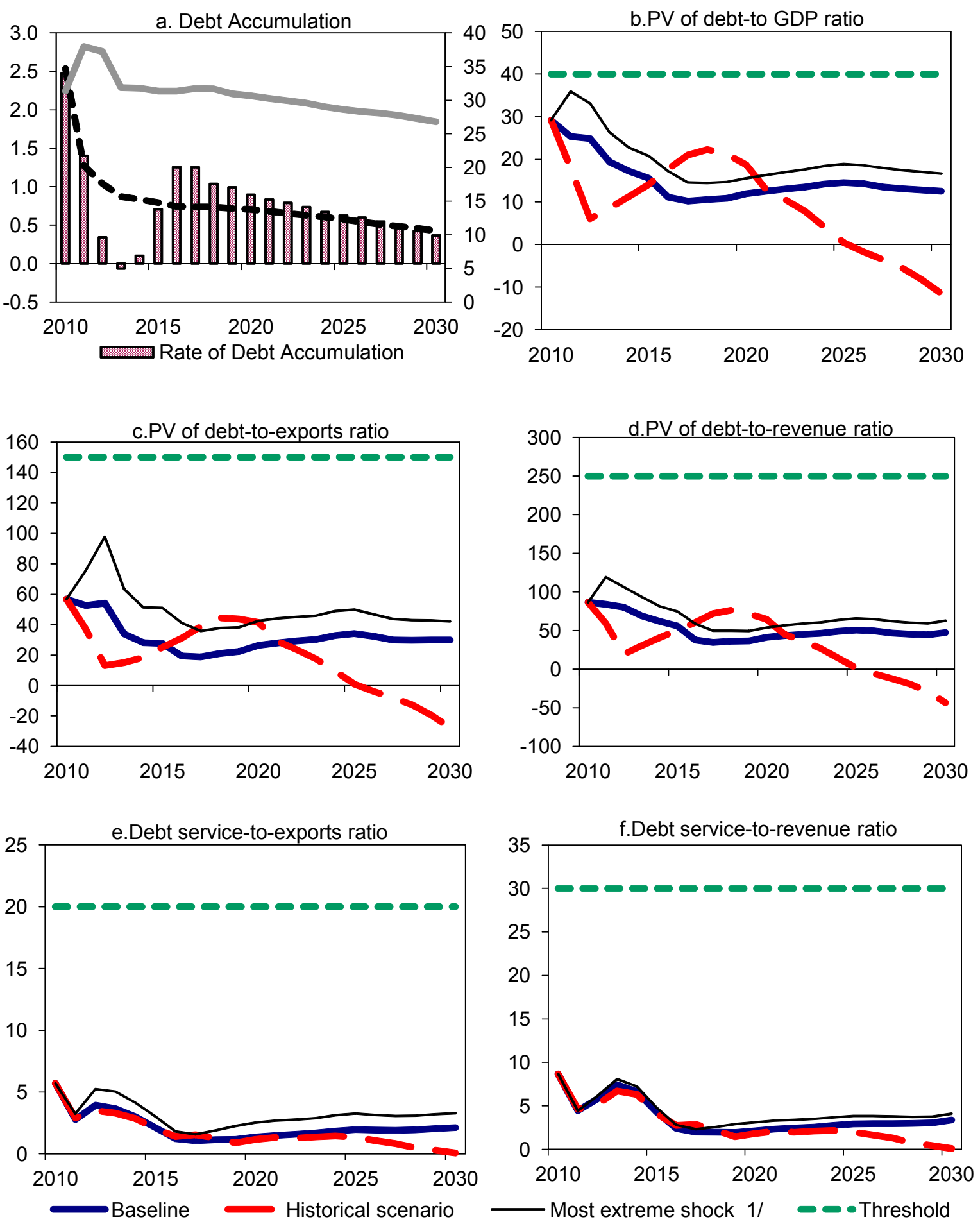

Sources: Mongolian authorities; and IMF staff estimates and projections.

1/ The most extreme stress test is the test that yields the highest ratio in 2020. In Figure b, it corresponds to a one-time depreciation shock; in c, to a exports shock; in d, to a one-time depreciation shock; in e, to a exports shock; and in f, to a exports shock. 
Figure 2. Mongolia: Indicators of Public Debt Under Alternative Scenarios, 2010-30 1/
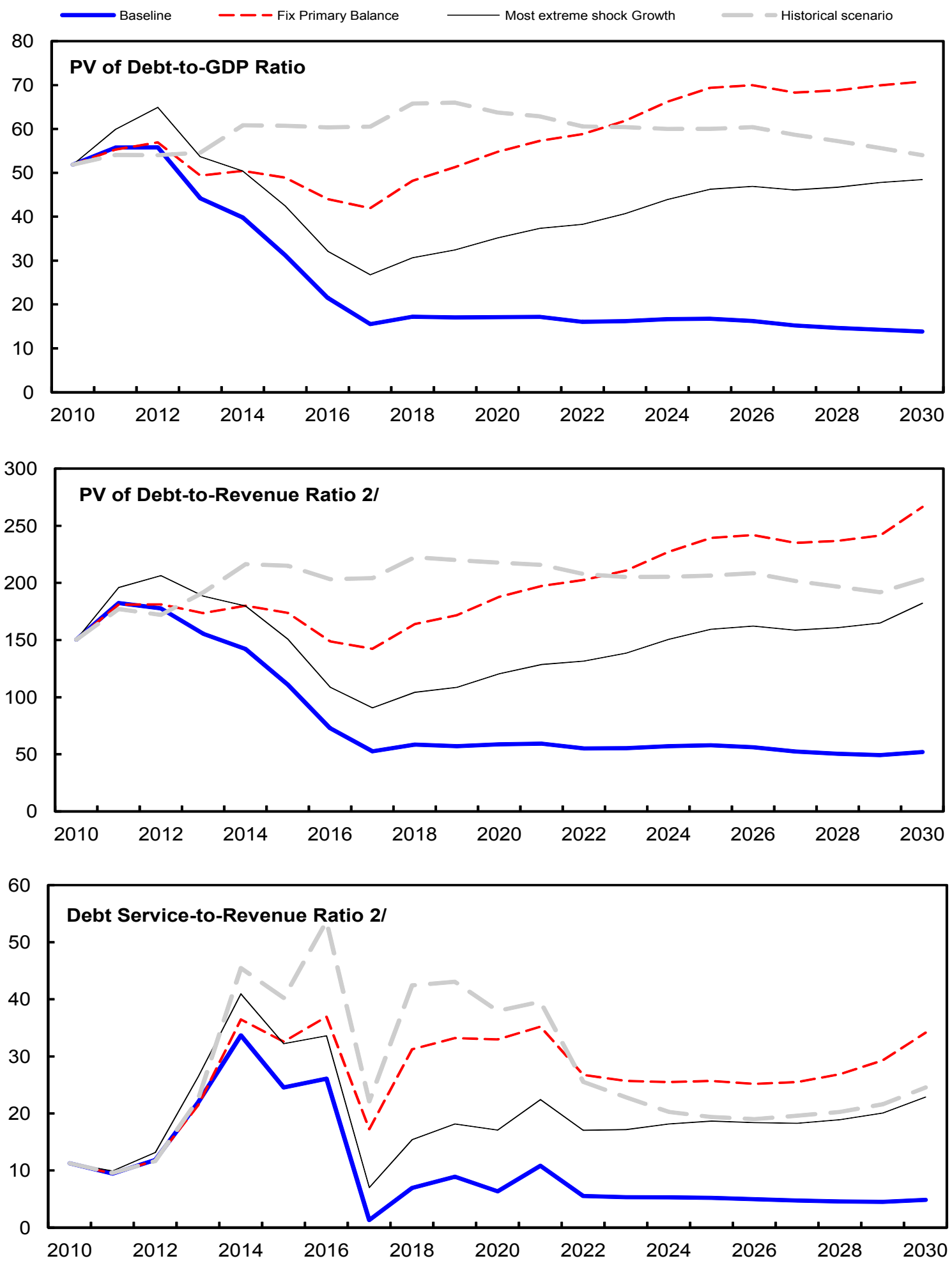

Sources: Mongolian authorities; and IMF staff estimates and projections.

$1 /$ The most extreme stress test is the test that yields the highest ratio in 2020 (growth).

2/ Revenues are defined inclusive of grants. 
Table 1. Mongolia: External Debt Sustainability Framework, Baseline Scenario, 2007-30 1/

(In percent of GDP, unless otherwise indicated)

\begin{tabular}{|c|c|c|c|c|c|c|c|c|c|c|c|c|c|c|c|}
\hline & \multicolumn{3}{|c|}{ Actual } & \multirow{2}{*}{$\begin{array}{l}\text { Historical } 6 \\
\text { Average }\end{array}$} & \multirow{2}{*}{$\begin{array}{l}\text { / Standard 6/ } \\
\text { Deviation }\end{array}$} & \multicolumn{6}{|c|}{ Projections } & \multirow[b]{2}{*}{$\begin{array}{c}2010-15 \\
\text { Average } \\
\end{array}$} & \multirow[b]{2}{*}{2020} & \multirow[b]{2}{*}{2030} & \multirow[b]{2}{*}{$\begin{array}{c}2016-30 \\
\text { Average } \\
\end{array}$} \\
\hline & 2007 & 2008 & 2009 & & & 2010 & 2011 & 2012 & 2013 & 2014 & 2015 & & & & \\
\hline External debt (nominal) $1 /$ & 40.1 & 34.6 & 50.0 & & & 52.7 & 60.4 & 79.2 & 60.1 & 46.3 & 36.8 & & 17.9 & 16.2 & \\
\hline Of which: public and publicly guaranteed (PPG) & 38.9 & 33.7 & 47.1 & & & 40.0 & 34.6 & 33.9 & 26.6 & 23.7 & 21.4 & & 16.0 & 15.9 & \\
\hline Change in external debt & -5.0 & -5.5 & 15.4 & & & 2.7 & 7.7 & 18.8 & -19.1 & -13.8 & -9.5 & & 0.6 & -0.5 & \\
\hline Identified net debt-creating flows & -24.8 & -11.7 & 3.3 & & & -0.2 & 4.2 & 4.8 & -25.4 & -18.0 & -14.5 & & -4.0 & -0.3 & \\
\hline Noninterest current account deficit & -7.1 & 13.7 & 5.1 & 2.6 & 7.2 & 10.4 & 20.6 & 17.7 & -1.3 & -6.3 & -6.3 & & -3.5 & 1.0 & -3.1 \\
\hline Deficit in balance of goods and services & -2.7 & 15.6 & 6.8 & & & 11.8 & 23.5 & 19.6 & -9.1 & -16.1 & -12.5 & & -7.6 & -0.6 & \\
\hline Exports & 64.2 & 58.3 & 55.3 & & & 51.3 & 48.2 & 45.9 & 57.1 & 61.1 & 56.3 & & 45.1 & 41.8 & \\
\hline Imports & 61.5 & 73.9 & 62.1 & & & 63.2 & 71.7 & 65.4 & 48.0 & 45.0 & 43.8 & & 37.5 & 41.2 & \\
\hline Net current transfers (negative $=$ inflow) & -5.5 & -3.5 & -3.8 & -8.3 & 3.3 & -2.9 & -2.3 & -2.3 & -1.7 & -1.4 & -1.2 & & -0.6 & -0.6 & -0.6 \\
\hline Of which: official & -3.4 & -1.7 & -0.9 & & & -0.6 & -0.4 & -0.5 & -0.3 & -0.2 & -0.1 & & 0.0 & 0.0 & \\
\hline Other current account flows (negative $=$ net inflow) & 1.1 & 1.6 & 2.2 & & & 1.5 & -0.5 & 0.5 & 9.5 & 11.3 & 7.4 & & 4.6 & 2.2 & \\
\hline Net FDI (negative = inflow) & -9.2 & -16.2 & -10.1 & -8.6 & 3.7 & -8.2 & -13.7 & -10.0 & -10.0 & -5.0 & -5.0 & & -1.0 & -1.0 & -1.5 \\
\hline Endogenous debt dynamics 21 & -8.5 & -9.1 & 8.3 & & & -2.4 & -2.7 & -3.0 & -14.2 & -6.7 & -3.2 & & 0.5 & -0.3 & \\
\hline Contribution from nominal interest rate & 0.4 & 0.3 & 0.5 & & & 0.6 & 0.4 & 0.4 & 3.5 & 2.9 & 2.0 & & 0.4 & 0.2 & \\
\hline Contribution from real GDP growth & -3.7 & -2.7 & 0.7 & & & -3.0 & -3.1 & -3.3 & -17.7 & -9.6 & -5.2 & & 0.1 & -0.5 & \\
\hline Contribution from price and exchange rate changes & -5.2 & -6.8 & 7.1 & & & & & & & & & & & & \\
\hline Residual (3-4) 3/ & 19.8 & 6.2 & 12.1 & & & 2.9 & 3.5 & 14.0 & 6.3 & 4.2 & 5.0 & & 4.6 & -0.2 & \\
\hline Of which: exceptional financing & 0.0 & 0.0 & 0.0 & & & 0.0 & 0.0 & 0.0 & 0.0 & 0.0 & 0.0 & & 0.0 & 0.0 & \\
\hline PV of external debt $4 /$ & $\ldots$ & $\ldots$ & 37.6 & & & 41.9 & 51.2 & 70.1 & 52.9 & 39.8 & 30.9 & & 13.8 & 12.8 & \\
\hline In percent of exports & $\ldots$ & $\ldots$ & 68.0 & & & 81.6 & 106.1 & 152.9 & 92.6 & 65.0 & 54.9 & & 30.5 & 30.6 & \\
\hline PV of PPG external debt & $\ldots$ & $\ldots$ & 34.7 & & & 29.1 & 25.3 & 24.8 & 19.4 & 17.2 & 15.6 & & 11.9 & 12.5 & \\
\hline In percent of exports & $\ldots$ & $\ldots$ & 62.8 & & & 56.8 & 52.6 & 54.2 & 34.0 & 28.1 & 27.7 & & 26.4 & 29.9 & \\
\hline In percent of government revenues & & $\ldots$ & 106.8 & & & 86.5 & 83.9 & 80.0 & 68.9 & 61.9 & $\begin{array}{lll}55.8 & & \\
\end{array}$ & & 41.2 & 47.2 & \\
\hline Debt service-to-exports ratio (in percent) & 4.3 & 2.8 & 3.7 & & & 5.7 & 2.8 & 3.9 & 14.1 & 17.4 & 13.3 & & 3.4 & 2.1 & \\
\hline PPG debt service-to-exports ratio (in percent) & 2.0 & 2.0 & 3.7 & & & 5.7 & 2.8 & 3.9 & 3.7 & 3.0 & 2.1 & & 1.4 & 2.1 & \\
\hline PPG debt service-to-revenue ratio (in percent) & 3.2 & 3.3 & 6.3 & & & 8.7 & 4.5 & 5.8 & 7.4 & 6.6 & 4.3 & & 2.1 & 3.4 & \\
\hline Total gross financing need (millions of U.S. dollars) & -531.9 & -45.9 & -103.1 & & & 283.0 & 553.4 & 707.1 & -207.3 & 6.6 & -349.7 & & -605.3 & 421.6 & \\
\hline Noninterest current account deficit that stabilizes debt ratio & -2.1 & 19.2 & -10.2 & & & 7.7 & 12.9 & -1.0 & 17.8 & 7.5 & 3.2 & & -4.1 & 1.5 & \\
\hline \multicolumn{16}{|l|}{ Key macroeconomic assumptions } \\
\hline Real GDP growth (in percent) & 10.2 & 8.9 & -1.6 & 6.0 & 4.1 & 7.3 & 7.1 & 6.1 & 27.9 & 18.6 & 12.8 & 13.3 & -0.8 & 3.4 & 5.1 \\
\hline GDP deflator in U.S. dollar terms (change in percent) & 13.0 & 20.3 & -17.0 & 9.3 & 12.0 & 14.3 & 12.4 & 3.7 & -2.3 & -1.8 & 0.6 & 4.5 & 3.0 & 2.1 & 2.7 \\
\hline Effective interest rate (percent) 5/ & 1.1 & 1.1 & 1.2 & 1.6 & 0.6 & 1.5 & 0.8 & 0.7 & 5.5 & 5.6 & 5.0 & 3.2 & 2.2 & 1.5 & 2.0 \\
\hline Growth of exports of G\&S (U.S. dollar terms, in percent) & 24.2 & 18.9 & -22.5 & 17.2 & 20.4 & 13.8 & 13.0 & 4.8 & 55.6 & 24.6 & 4.6 & 19.4 & -5.1 & 3.1 & 6.0 \\
\hline Growth of imports of G\&S (U.S. dollar terms, in percent) & 28.5 & 57.4 & -31.4 & 16.6 & 22.3 & 24.7 & 36.5 & 0.5 & -8.3 & 9.1 & 10.6 & 12.2 & 2.0 & 7.4 & 7.4 \\
\hline Grant element of new public sector borrowing (in percent) & & & & $\ldots$ & $\ldots$ & 31.4 & 38.0 & 37.3 & 31.9 & 31.8 & 31.4 & 33.6 & 30.7 & 26.8 & 29.5 \\
\hline Government revenues (excluding grants, in percent of GDP) & 40.4 & 35.8 & 32.5 & & & 33.7 & 30.2 & 31.1 & 28.2 & 27.8 & 27.9 & & 28.9 & 26.4 & 28.8 \\
\hline Aid flows (in millions of U.S. dollars) 71 & 18.8 & 13.8 & 17.0 & & & 41.9 & 22.0 & 24.4 & 24.4 & 25.2 & 26.3 & & 54.6 & 51.3 & \\
\hline Of which: Grants & 18.8 & 13.8 & 17.0 & & & 41.9 & 22.0 & 24.4 & 24.4 & 25.2 & 26.3 & & 54.6 & 51.3 & \\
\hline Of which: Concessional loans & 0.0 & 0.0 & 0.0 & & & 0.0 & 0.0 & 0.0 & 0.0 & 0.0 & 0.0 & & 0.0 & 0.0 & \\
\hline Grant-equivalent financing (in percent of GDP) 8 / & $\ldots$ & $\ldots$ & $\ldots$ & & & 2.5 & 1.3 & 1.0 & 0.9 & 0.8 & 0.8 & & 0.7 & 0.4 & 0.6 \\
\hline Grant-equivalent financing (in percent of external financing) 8/ & $\ldots$ & $\ldots$ & $\ldots$ & & & 40.2 & 45.9 & 47.5 & 41.1 & 40.1 & 39.3 & & 39.9 & 36.0 & 38.5 \\
\hline \multicolumn{16}{|l|}{ Memorandum items: } \\
\hline Nominal dollar GDP growth & 24.5 & 31.0 & -18.4 & & & 22.6 & 20.3 & 10.0 & 24.9 & 16.5 & 13.5 & 18.0 & 2.2 & 5.6 & 8.1 \\
\hline PV of PPG external debt (in millions of U.S. dollars) & & & 1457.3 & & & 1561.4 & 1633.5 & 1654.5 & 1649.9 & 1658.3 & 1728.4 & & 2664.7 & 2235.8 & \\
\hline (PVt-PVt-1)/GDPt-1 (in percent) & & & & & & 2.5 & 1.4 & 0.3 & -0.1 & 0.1 & 0.7 & 0.8 & 0.9 & 0.4 & 0.8 \\
\hline Gross remittances (Millions of US dollars) & 83.9 & 94.2 & 120.5 & & & 120.5 & 121.1 & 121.7 & 122.3 & 122.9 & 123.5 & & 138.0 & 195.7 & \\
\hline PV of PPG external debt (in percent of GDP + remittances & & $\ldots$ & 33.8 & & & 28.5 & 24.9 & 24.4 & 19.1 & 17.0 & 15.4 & & 11.8 & 12.4 & \\
\hline PV of PPG external debt (in percent of exports + remittances) & $\ldots$ & $\ldots$ & 59.7 & & & 54.3 & 50.6 & 52.1 & 33.1 & 27.6 & 27.1 & & 26.1 & 29.5 & \\
\hline Debt service of PPG external debt (in percent of exports + remittances) & & $\ldots$ & 3.5 & & & 5.5 & 2.7 & 3.8 & 3.6 & 3.0 & 2.1 & & 1.3 & 2.1 & \\
\hline
\end{tabular}

Sources: Mongolian authorities; and IMF staff estimates and projections.

$1 /$ Includes both public and private sector external debt.

2/ Derived as $[r-g-\rho(1+g)](1+g+\rho+g \rho)$ times previous period debt ratio, with $r=$ nominal interest rate; $g=$ real GDP growth rate, and $\rho=$ growth rate of GDP deflator in U.S. dollar terms.

$3 /$ Includes exceptional financing (i.e., changes in arrears and debt relief); changes in gross foreign assets; and valuation adjustments. For projections also includes contribution from price and exchange rate changes.

4/ Assumes that PV of private sector debt is equivalent to its face value.

$5 /$ Current-year interest payments divided by previous period debl stock.

6/ Historical averages and standard deviations are generally derived over the past 10 years, subject to data availability.

8/ Grant-equivalent financing includes grants provided directly to the government and through new borrowing (difference between the face value and the PV of new debt). 
Table 2. Mongolia: Public Sector Debt Sustainability Framework, Baseline Scenario, 2007-30 (In percent of GDP, unless otherwise indicated)

\begin{tabular}{|c|c|c|c|c|c|c|c|c|c|c|c|c|c|c|c|}
\hline & \multicolumn{3}{|c|}{ Actual } & \multirow[b]{2}{*}{ Average 5} & \multirow[b]{2}{*}{$\begin{array}{l}\text { Standard } \\
\text { Deviation }\end{array}$} & \multicolumn{4}{|l|}{ Estimate } & \multicolumn{2}{|c|}{ Projections } & \multirow[b]{2}{*}{$\begin{array}{l}2010-15 \\
\text { Average }\end{array}$} & \multirow[b]{2}{*}{2020} & \multirow[b]{2}{*}{2030} & \multirow[b]{2}{*}{$\begin{array}{l}2016-30 \\
\text { Average }\end{array}$} \\
\hline & 2007 & 2008 & 2009 & & & 5/ 2010 & 2011 & 2012 & 2013 & 2014 & 2015 & & & & \\
\hline $\begin{array}{l}\text { Public sector debt } 1 / \\
\text { Of which: foreign-currency denominated }\end{array}$ & $\begin{array}{l}39.4 \\
38.9\end{array}$ & $\begin{array}{l}33.8 \\
33.7\end{array}$ & $\begin{array}{l}56.4 \\
49.5\end{array}$ & & & $\begin{array}{l}62.7 \\
51.9\end{array}$ & $\begin{array}{l}65.0 \\
53.6\end{array}$ & $\begin{array}{l}64.9 \\
52.8\end{array}$ & $\begin{array}{l}51.4 \\
40.9\end{array}$ & $\begin{array}{l}46.3 \\
36.0\end{array}$ & $\begin{array}{l}37.1 \\
28.3\end{array}$ & & $\begin{array}{l}21.2 \\
16.0\end{array}$ & $\begin{array}{l}17.2 \\
15.9\end{array}$ & \\
\hline Change in public sector debt & -5.0 & -5.6 & 22.6 & & & 6.3 & 2.3 & -0.1 & -13.5 & -5.1 & -9.3 & & 0.4 & -0.6 & \\
\hline Identified debt-creating flows & -11.7 & -2.0 & 9.4 & & & -0.9 & -5.7 & -0.6 & -13.0 & -8.8 & -11.6 & & 0.0 & -1.5 & \\
\hline Primary deficit & -3.3 & 4.6 & 5.0 & 0.6 & 4.4 & 2.7 & 3.2 & 0.8 & -2.2 & -4.5 & -7.0 & -1.2 & -0.5 & -0.8 & -1.9 \\
\hline Revenue and grants & 40.9 & 36.1 & 32.9 & & & 34.5 & 30.6 & 31.4 & 28.4 & 28.0 & 28.1 & & 29.2 & 26.6 & \\
\hline Of which: grants & 0.5 & 0.3 & 0.4 & & & 0.8 & 0.4 & 0.4 & 0.3 & 0.3 & 0.2 & & 0.2 & 0.1 & \\
\hline Primary (noninterest) expenditure & 37.6 & 40.6 & 37.9 & & & 37.2 & 33.7 & 32.3 & 26.2 & 23.5 & 21.2 & & 28.6 & 25.8 & \\
\hline Automatic debt dynamics & -8.0 & -6.4 & 4.9 & & & -10.5 & -8.6 & -1.3 & -10.6 & -4.2 & -4.5 & & 0.6 & -0.6 & \\
\hline Contribution from interest rate/growth differential & -8.4 & -8.9 & 8.1 & & & -8.9 & -8.6 & -4.4 & -9.7 & -5.1 & -4.1 & & 0.0 & -0.6 & \\
\hline Of which: contribution from average real interest rate & -4.2 & -5.7 & 7.5 & & & -5.0 & -4.5 & -0.7 & 4.5 & 2.9 & 1.2 & & -0.2 & 0.0 & \\
\hline Of which: contribution from real GDP growth & -4.1 & -3.2 & 0.6 & & & -3.8 & -4.2 & -3.7 & -14.2 & -8.1 & -5.3 & & 0.2 & -0.6 & \\
\hline Contribution from real exchange rate depreciation & 0.4 & 2.5 & -3.2 & & & -1.6 & 0.0 & 3.2 & -1.0 & 1.0 & -0.4 & & & $\ldots$ & \\
\hline Other identified debt-creating flows & -0.4 & -0.1 & -0.4 & & & 6.9 & -0.2 & -0.2 & -0.2 & -0.1 & -0.1 & & -0.1 & 0.0 & \\
\hline Privatization receipts (negative) & -0.4 & -0.1 & -0.4 & & & -0.3 & -0.2 & -0.2 & -0.2 & -0.1 & -0.1 & & -0.1 & 0.0 & \\
\hline Recognition of implicit or contingent liabilities & 0.0 & 0.0 & 0.0 & & & 0.0 & 0.0 & 0.0 & 0.0 & 0.0 & 0.0 & & 0.0 & 0.0 & \\
\hline Debt relief (HIPC and other) & 0.0 & 0.0 & 0.0 & & & 0.0 & 0.0 & 0.0 & 0.0 & 0.0 & 0.0 & & 0.0 & 0.0 & \\
\hline Other (bank recapitalization) & 0.0 & 0.0 & 0.0 & & & 7.2 & 0.0 & 0.0 & 0.0 & 0.0 & 0.0 & & 0.0 & 0.0 & \\
\hline Residual, including asset changes & 6.7 & -3.6 & 13.2 & & & 7.2 & 8.0 & 0.5 & -0.5 & 3.7 & 2.3 & & 0.4 & 0.8 & \\
\hline \multicolumn{16}{|l|}{ Other Sustainability Indicators } \\
\hline PV of public sector debt & 0.5 & 0.0 & 44.0 & & & 51.9 & 55.8 & 55.8 & 44.2 & 39.8 & 31.2 & & 17.1 & 13.8 & \\
\hline Of which: foreign-currency denominated & 0.0 & 0.0 & 37.1 & & & 41.1 & 44.3 & 43.7 & 33.7 & 29.5 & 22.5 & & 11.9 & 12.5 & \\
\hline Of which: external & $\ldots$ & $\ldots$ & 34.7 & & & 29.1 & 25.3 & 24.8 & 19.4 & 17.2 & 15.6 & & 11.9 & 12.5 & \\
\hline PV of contingent liabilities (not included in public sector debt) & ... & $\ldots$ & & & & $\ldots$ & & $\ldots$ & & ... & $\ldots$ & & $\ldots$ & $\ldots$ & \\
\hline Gross financing need 21 & -1.1 & 6.5 & 7.1 & & & 9.1 & 6.1 & 4.6 & 4.0 & 4.9 & -0.1 & & 1.3 & 0.5 & \\
\hline $\mathrm{PV}$ of public sector debt-to-revenue and grants ratio (in percent) & 1.2 & 0.1 & 133.7 & & & 150.3 & 182.5 & 177.8 & 155.4 & 142.1 & 110.9 & & 58.6 & 52.0 & \\
\hline PV of public sector debt-to-revenue ratio (in percent) & 1.2 & 0.1 & 135.3 & & & 153.9 & 184.6 & 179.8 & 157.0 & 143.4 & 111.9 & & 59.1 & 52.3 & \\
\hline Of which: external $3 /$ & & & 106.8 & & & 86.5 & 83.9 & 80.0 & 68.9 & 61.9 & 55.8 & & 41.2 & 47.2 & \\
\hline Debt service-to-revenue and grants ratio (in percent) $4 /$ & 5.5 & 4.5 & 6.4 & & & 11.3 & 9.5 & 11.9 & 21.9 & 33.7 & 24.6 & & 6.4 & 4.9 & \\
\hline Debt service-to-revenue ratio (in percent) $4 /$ & 5.5 & 4.5 & 6.5 & & & 11.6 & 9.6 & 12.0 & 22.2 & 34.0 & 24.8 & & 6.4 & 4.9 & \\
\hline Primary deficit that stabilizes the debt-to-GDP ratio & 1.7 & 10.2 & -17.7 & & & -3.7 & 0.9 & 1.0 & 11.3 & 0.6 & 2.3 & & -0.9 & -0.2 & \\
\hline \multicolumn{16}{|l|}{ Key macroeconomic and fiscal assumptions } \\
\hline Real GDP growth (in percent) & 10.2 & 8.9 & -1.6 & 6.0 & 4.1 & 7.3 & 7.1 & 6.1 & 27.9 & 18.6 & 12.8 & 13.3 & -0.8 & 3.4 & 5.1 \\
\hline Average nominal interest rate on forex debt (in percent) & 1.1 & 1.1 & 1.2 & 1.7 & 0.6 & 1.5 & 0.8 & 0.7 & 6.3 & 4.5 & 3.1 & 2.8 & 1.3 & 1.5 & 1.4 \\
\hline Average real interest rate on domestic debt (in percent) & & -4.6 & 80.3 & 17.1 & 29.0 & 1.7 & 5.0 & 7.0 & 9.2 & 8.0 & 4.3 & 5.9 & 1.3 & 4.5 & 4.7 \\
\hline Real exchange rate depreciation (in percent, + indicates depreciation) & 1.0 & 8.4 & -7.6 & -0.3 & 4.0 & & $\ldots$ & & $\ldots$ & & $\ldots$ & & & & \\
\hline Inflation rate (GDP deflator, in percent) & 12.3 & 20.2 & 2.2 & 12.6 & 7.3 & 11.2 & 4.2 & 2.3 & 0.3 & 1.4 & 5.1 & 4.1 & 7.3 & 5.3 & 4.8 \\
\hline Growth of real primary spending (deflated by GDP deflator, in percent) & 0.5 & 0.2 & -0.1 & 0.1 & 0.2 & 0.1 & 0.0 & 0.0 & 0.0 & 0.1 & 0.0 & 0.0 & 0.0 & -0.1 & 0.1 \\
\hline Grant element of new external borrowing (in percent) & & & & & $\ldots$ & 31.4 & 38.0 & 37.3 & 31.9 & 31.8 & 31.4 & 33.6 & 30.7 & 26.8 & \\
\hline
\end{tabular}

Sources: Mongolian authorities; and IMF staff estimates and projections.

overnment, on a gross basis.

the primary deficit plus debt service plus the stock of short-term debt at the end of the last period.

4/ Revenues excluding grants.

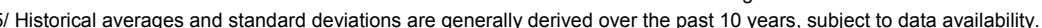


Table 3a. Mongolia: Sensitivity Analysis for Key Indicators of Public and Publicly Guaranteed External Debt, 2010-30 (In percent)

Projections

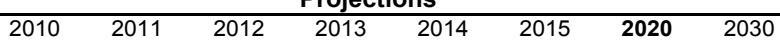

\section{PV of debt-to GDP ratio}

Baseline

A. Alternative Scenarios

A1. Key variables at their historical averages in 2010-30 1/

A2. New public sector loans on less favorable terms in 2010-30 2

A3. High-investment, low-growth scenario

\section{B. Bound Tests}

B1. Real GDP growth at historical average minus one standard deviation in 2011-12

B2. Export value growth at historical average minus one standard deviation in 2011-12 3/

B3. U.S. dollar GDP deflator at historical average minus one standard deviation in 2011-12

B4. Net nondebt creating flows at historical average minus one standard deviation in 2011-12 4/

B5. Combination of B1-B4 using one-half standard deviation shocks

B6. One-time 30 percent nominal depreciation relative to the baseline in 2011 5/

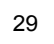

9

25

25

19

17

16

12

12

$29 \quad 18$

29

29

27

25

6
25

9
21
30

11
18

38

14
17

17

$\begin{array}{rr}19 & -12 \\ 15 & 18\end{array}$

$28 \quad 14$

$\begin{array}{llllllll}29 & 28 & 27 & 21 & 18 & 17 & \mathbf{1 2} & 13 \\ 29 & 31 & 36 & 29 & 25 & 23 & \mathbf{1 5} & 14 \\ 29 & 30 & 30 & 24 & 20 & 19 & \mathbf{1 4} & 15 \\ 29 & 31 & 30 & 24 & 21 & 19 & \mathbf{1 3} & 13 \\ 29 & 35 & 35 & 28 & 24 & 22 & \mathbf{1 5} & 15 \\ 29 & 36 & 33 & 26 & 23 & 21 & \mathbf{1 6} & 17\end{array}$

PV of debt-to-exports ratio

Baseline

A. Alternative Scenarios

A1. Key variables at their historical averages in 2010-30 1/

A2. New public sector loans on less favorable terms in 2010-30 2

A3. High-investment, low-growth scenario

\section{B. Bound Tests}

B1. Real GDP growth at historical average minus one standard deviation in 2011-12

B2. Export value growth at historical average minus one standard deviation in 2011-12 3/

B3. U.S. dollar GDP deflator at historical average minus one standard deviation in 2011-12

B4. Net nondebt creating flows at historical average minus one standard deviation in 2011-12 4/

B5. Combination of B1-B4 using one-half standard deviation shocks

B6. One-time 30 percent nominal depreciation relative to the baseline in 2011 5/

$\begin{array}{llllllll}57 & 55 & 53 & 34 & 27 & 27 & \mathbf{2 5} & 29 \\ 57 & 76 & 98 & 63 & 51 & 51 & \mathbf{4 3} & 42 \\ 57 & 55 & 53 & 34 & 27 & 27 & \mathbf{2 5} & 29 \\ 57 & 64 & 66 & 42 & 34 & 34 & \mathbf{3 0} & 31 \\ 57 & 68 & 68 & 44 & 35 & 35 & \mathbf{3 1} & 32 \\ 57 & 55 & 53 & 34 & 27 & 27 & \mathbf{2 5} & 29\end{array}$

PV of debt-to-revenue ratio

Baseline

\section{A. Alternative Scenarios}

A1. Key variables at their historical averages in 2010-30 1/

A2. New public sector loans on less favorable terms in 2010-30 2/

A3. High-investment, low-growth scenario

\section{B. Bound Tests}

B1. Real GDP growth at historical average minus one standard deviation in 2011-12

B2. Export value growth at historical average minus one standard deviation in 2011-12 3/

B3. U.S. dollar GDP deflator at historical average minus one standard deviation in 2011-12

B4. Net nondebt creating flows at historical average minus one standard deviation in 2011-12 4/

B5. Combination of B1-B4 using one-half standard deviation shocks

B6. One-time 30 percent nominal depreciation relative to the baseline in 20115 /

$\begin{array}{rrrrrrr}59 & 19 & 31 & 41 & 50 & \mathbf{6 5} & -44 \\ 89 & 82 & 74 & 66 & 62 & \mathbf{5 0} & 69 \\ 84 & 82 & 95 & 112 & 103 & \mathbf{5 6} & 31\end{array}$

$\begin{array}{rrrrrrrr}86 & 92 & 85 & 75 & 65 & 60 & \mathbf{4 3} & 50 \\ 86 & 103 & 114 & 102 & 90 & 82 & \mathbf{5 2} & 53 \\ 86 & 101 & 96 & 84 & 74 & 67 & \mathbf{4 9} & 57 \\ 86 & 102 & 97 & 86 & 75 & 69 & \mathbf{4 6} & 49 \\ 86 & 115 & 112 & 99 & 87 & 79 & \mathbf{5 3} & 57 \\ 86 & 119 & 107 & 94 & 82 & 74 & \mathbf{5 4} & 63\end{array}$


Table 3b. Mongolia: Sensitivity Analysis for Key Indicators of Public and Publicly Guaranteed External Debt, 2010-30 (continued) (In percent)

\begin{tabular}{|c|c|c|c|c|c|}
\hline \multicolumn{6}{|c|}{ Projections } \\
\hline 2010 & 2011 & 2013 & 2015 & 2020 & 2030 \\
\hline
\end{tabular}

\section{Debt service-to-exports ratio}

\section{Baseline}

\section{A. Alternative Scenarios}

A1. Key variables at their historical averages in 2010-30 1/ A2. New public sector loans on less favorable terms in 2010-30 2/ A3. High-investment, low-growth scenario

\section{B. Bound Tests}

B1. Real GDP growth at historical average minus one standard deviation in 2011-12

B2. Export value growth at historical average minus one standard deviation in 2011-12 3

B3. U.S. dollar GDP deflator at historical average minus one standard deviation in 2011-12

B4. Net nondebt creating flows at historical average minus one standard deviation in 2011-12 4/

B5. Combination of B1-B4 using one-half standard deviation shocks

B6. One-time 30 percent nominal depreciation relative to the baseline in 20115 /

$6 \quad 3$

63

3

3

4

$4-3$

4

$\begin{array}{llll}3 & 2 & 1 & 0 \\ 2 & 2 & 2 & 3\end{array}$

$\begin{array}{llllllll}6 & 3 & 4 & 4 & 3 & 2 & \mathbf{1} & 2 \\ 6 & 3 & 5 & 5 & 4 & 3 & \mathbf{3} & 3 \\ 6 & 3 & 4 & 4 & 3 & 2 & \mathbf{1} & 2 \\ 6 & 3 & 4 & 4 & 3 & 2 & \mathbf{2} & 2 \\ 6 & 3 & 4 & 4 & 3 & 2 & \mathbf{2} & 2 \\ 6 & 3 & 4 & 4 & 3 & 2 & \mathbf{1} & 2\end{array}$

\section{Debt service-to-revenue ratio}

\section{Baseline}

\section{A. Alternative Scenarios}

A1. Key variables at their historical averages in 2010-30 1/

A2. New public sector loans on less favorable terms in 2010-30 2/

A3. High-investment, low-growth scenario

\section{B. Bound Tests}

B1. Real GDP growth at historical average minus one standard deviation in 2011-12

B2. Export value growth at historical average minus one standard deviation in 2011-12 3/

B3. U.S. dollar GDP deflator at historical average minus one standard deviation in 2011-12

B4. Net nondebt creating flows at historical average minus one standard deviation in 2011-12 4/

B5. Combination of B1-B4 using one-half standard deviation shocks

B6. One-time 30 percent nominal depreciation relative to the baseline in 2011 5/

Memorandum item:

Grant element assumed on residual financing (i.e., financing required above baseline) 6/

(20)

$\begin{array}{llllllll}9 & 5 & 5 & 7 & 6 & 4 & \mathbf{2} & 0 \\ 9 & 4 & 6 & 7 & 5 & 3 & \mathbf{3} & 5 \\ 9 & 4 & 6 & 7 & 7 & 5 & \mathbf{2} & 3\end{array}$

Sources: Mongolian authorities; and IMF staff estimates and projections.

1/ Variables include real GDP growth, growth of GDP deflator (in U.S. dollar terms), noninterest current account in percent of GDP, and nondebt creating flows

$2 /$ Assumes that the interest rate on new borrowing is by 2 percentage points higher than in the baseline, while grace and maturity periods are the same as in the baseline.

$3 /$ Exports values are assumed to remain permanently at the lower level, but the current account as a share of GDP is assumed to return to its baseline level after the shock (implicitly assuming an offsetting adjustment in import levels).

4/ Includes official and private transfers and FDI.

5/ Depreciation is defined as percentage decline in dollar/local currency rate, such that it never exceeds 100 percent.

6/ Applies to all stress scenarios except for A2 (less favorable financing) in which the terms on all new financing are as specified in footnote 2 . 
Table 4. Mongolia: Sensitivity Analysis for Key Indicators of Public Debt 2010-30

\begin{tabular}{|c|c|c|c|c|c|c|c|c|}
\hline & \multicolumn{8}{|c|}{ Projections } \\
\hline & 2010 & 2011 & 2012 & 2013 & 2014 & 2015 & 2020 & 2030 \\
\hline \multicolumn{9}{|l|}{ PV of Debt-to-GDP Ratio } \\
\hline Baseline & 52 & 56 & 56 & 44 & 40 & 31 & 17 & 14 \\
\hline \multicolumn{9}{|l|}{ A. Alternative scenarios } \\
\hline A1. Real GDP growth and primary balance are at historical averages & 52 & 54 & 54 & 55 & 61 & 61 & 64 & 54 \\
\hline A2. Primary balance is unchanged from 2010 & 52 & 55 & 57 & 49 & 50 & 49 & 55 & 71 \\
\hline A3. Permanently lower GDP growth $1 /$ & 52 & 56 & 57 & 46 & 43 & 35 & 28 & 55 \\
\hline \multicolumn{9}{|l|}{ B. Bound tests } \\
\hline B1. Real GDP growth is at historical average minus one standard deviations in $2011-12$ & 52 & 60 & 65 & 54 & 50 & 42 & 35 & 48 \\
\hline B2. Primary balance is at historical average minus one standard deviations in $2011-12$ & 52 & 57 & 61 & 48 & 43 & 34 & 19 & 15 \\
\hline B3. Combination of B1-B2 using one half standard deviation shocks & 52 & 57 & 60 & 49 & 45 & 37 & 27 & 33 \\
\hline B4. One-time 30 percent real depreciation in 2011 & 52 & 69 & 69 & 55 & 50 & 40 & 21 & 19 \\
\hline B5. 10 percent of GDP increase in other debt-creating flows in 2011 & 52 & 64 & 64 & 51 & 46 & 36 & 20 & 16 \\
\hline \multicolumn{9}{|c|}{ PV of Debt-to-Revenue Ratio 2/ } \\
\hline Baseline & 150 & 182 & 178 & 155 & 142 & 111 & 59 & 52 \\
\hline \multicolumn{9}{|l|}{ A. Alternative scenarios } \\
\hline $\begin{array}{l}\text { A1. Real GDP growth and primary balance are at historical averages } \\
\text { A2. Primary balance is unchanged from } 2010 \\
\text { A3. Permanently lower GDP growth } 1 /\end{array}$ & $\begin{array}{l}150 \\
150 \\
150\end{array}$ & $\begin{array}{l}177 \\
181 \\
185\end{array}$ & $\begin{array}{l}172 \\
181 \\
183\end{array}$ & $\begin{array}{l}192 \\
173 \\
163\end{array}$ & $\begin{array}{l}216 \\
180 \\
153\end{array}$ & $\begin{array}{l}215 \\
174 \\
124\end{array}$ & $\begin{array}{r}218 \\
188 \\
97\end{array}$ & $\begin{array}{l}203 \\
266 \\
208\end{array}$ \\
\hline \multicolumn{9}{|l|}{ B. Bound tests } \\
\hline $\begin{array}{l}\text { B1. Real GDP growth is at historical average minus one standard deviations in 2011-12 } \\
\text { B2. Primary balance is at historical average minus one standard deviations in 2011-12 } \\
\text { B3. Combination of B1-B2 using one half standard deviation shocks } \\
\text { B4. One-time } 30 \text { percent real depreciation in } 2011 \\
\text { B5. } 10 \text { percent of GDP increase in other debt-creating flows in } 2011\end{array}$ & $\begin{array}{l}150 \\
150 \\
150 \\
150 \\
150\end{array}$ & $\begin{array}{l}196 \\
188 \\
187 \\
226 \\
182\end{array}$ & $\begin{array}{l}206 \\
194 \\
191 \\
219 \\
179\end{array}$ & $\begin{array}{l}189 \\
170 \\
171 \\
194 \\
181\end{array}$ & $\begin{array}{l}180 \\
155 \\
161 \\
179 \\
192\end{array}$ & $\begin{array}{l}151 \\
122 \\
131 \\
144 \\
158\end{array}$ & $\begin{array}{r}120 \\
65 \\
92 \\
74 \\
74\end{array}$ & $\begin{array}{r}182 \\
58 \\
122 \\
72 \\
36\end{array}$ \\
\hline \multicolumn{9}{|c|}{ Debt Service-to-Revenue Ratio 2/ } \\
\hline Baseline & 11 & 9 & 12 & 22 & 34 & 25 & 6 & 5 \\
\hline \multicolumn{9}{|l|}{ A. Alternative scenarios } \\
\hline A1. Real GDP growth and primary balance are at historical averages & 11 & 10 & 12 & 22 & 45 & 40 & 38 & 25 \\
\hline A2. Primary balance is unchanged from 2010 & 11 & 9 & 12 & 21 & 36 & 33 & 33 & 34 \\
\hline A3. Permanently lower GDP growth $1 /$ & 11 & 10 & 12 & 23 & 36 & 27 & 13 & 27 \\
\hline \multicolumn{9}{|l|}{ B. Bound tests } \\
\hline B1. Real GDP growth is at historical average minus one standard deviations in $2011-12$ & 11 & 10 & 13 & 26 & 41 & 32 & 17 & 23 \\
\hline B2. Primary balance is at historical average minus one standard deviations in 2011-12 & 11 & 9 & 12 & 25 & 39 & 26 & 7 & 6 \\
\hline B3. Combination of B1-B2 using one half standard deviation shocks & 11 & 10 & 12 & 23 & 38 & 28 & 12 & 15 \\
\hline B4. One-time 30 percent real depreciation in 2011 & 11 & 10 & 14 & 28 & 39 & 30 & 9 & 9 \\
\hline B5. 10 percent of GDP increase in other debt-creating flows in 2011 & 11 & 9 & 13 & 35 & 35 & 30 & 7 & 7 \\
\hline
\end{tabular}

Sources: Mongolian authorities; and IMF staff estimates and projections.

$1 /$ Assumes that real GDP growth is at baseline minus one standard deviation divided by the square root of the length of the projection period.

2/ Revenues are defined inclusive of grants. 